\title{
DEVELOPMENT OF INDONESIAN SHARIA BANKS WITH MALAYSIA COMPARATION METHOD (STUDY OF HISTORY, PRODUCTS AND LEGAL ASSETS)
}

\author{
Hagi Hutomo Mukti \\ Faculty Of Law, Universitas Negeri Semarang, K1 Building, \\ Sekaran Gunungpati, Semarang, Indonesia Telp/Fax. (024) 8507891-70709205 \\ Email:hagihutomo@gmail.com \\ Submitted :23/01/2020 Reviewed: 24/03/2020 Accepted: 31/03/2020
}

\begin{abstract}
Sharia banking is developed in response to economic and cultural groups that are used to accommodate those who want the services to be carried out with Islamic sharia principles and morals. The development of Sharia banks in Indonesia and Malaysia needs to be studied more deeply because Malaysia first established Sharia banks in 1983 through Bank Islam Malaysia Berhad (BIMB) while the first sharia bank in Indonesia, which named Bank Muamalat, was burned in 1991, which determines the direction of the progress of sharia banks in Indonesia with the provisions of Law Number 10 of 1998 concerning Banking. Determine the amount of assets from banks that have a ratio of 1: 10 with Malaysia considering the assets of sharia banks in Indonesia amounted to US \$35.62 billion while Malaysia reached US \$ 423.2 billion. This study focuses on the factors and effects of legal products from the two countries in order to get more comprehensive study and know the relation between the legal products with sharia banking development in Indonesia and Malaysia.
\end{abstract}

Keywords: Islamic Bank; Comparison; Indonesia; Malaysia.

\section{INTRODUCTION}

The Bank is a financial institution that has an important role in the economy of a country as a financial intermediary. Bank, in Article 1 paragraph (2) Law No. 10 of 1998 concerning amendment to Law No. 7 of 1992 concerning banking, is a corporate entity mobilizing funds from the public in the forms of Deposits and channeling them to the public in the forms of Credit and/or other forms in order to improve the living standards of the common people. While Islamic Banks are banks that follow the Islamic economic system. As for the Islamic economy according to Fazlurrahman, "Islamic economics according to the builders and supporters are built on or at least colored by the religious principles, world-oriented and the hereafter." In 1992 Bank Muamalat Indonesia was established as a sign of the dual definition of banks, commercial banks and 
banks People's Credit in Law Number 10 of 1998 Article 1 concerning banking, namely: "Bank is a corporate entity mobilizing funds from the public in the forms of Deposits and channeling them to the public in the forms of Credit and/or other forms in order to improve the living standards of the common people". While the definition of a Commercial Bank is a Bank which based its activities on conventional and/or Syariah Principles in doing so provides services in payment transactions. ${ }^{1}$ Law Number 10 of 1998 Article 1 Paragraph 13 concerning banking states what is meant by sharia principles, namely:

"Syariah Principles are rules of agreement based on Islamic Law between Bank and other party for depositing fund and/or financing business activities, or other activities which is stated as in accordance to Syariah Principles, i.e. financing based on profit sharing principle (mudharabah), financing based on equity participation (musharakah), sales of goods with profit principle (murabahah), or financing of capital goods based on pure lease without option (ijarah) or with an option of ownership transfer of goods leased from Bank to the other party (ijarah wa iqtina)".

Whereas in Law Number 21 of 2008 article 1 paragraph 12 concerning Islamic Banking states that what is meant by sharia principles is the Islamic law principles in the banking business based on the fatwa issued by an institution having the authority in stipulating fatwa in sharia matters. From the definition of the bank mentioned above, it can be concluded that a Sharia Bank is a corporate en-

1 M. Shabri Abd. Majid. 2014. "Regulasi Perbankan Syariah: Studi Komparatif Antara Malaysia Dan Indonesia”. jurnal Media Syariah, 16(1): 235 tity that carries out its intermediary function based on sharia principles or in other words the bank in its activities, both fund raising and distribution of funds provides compensation on the basis of sharia principles.

The position of Islamic banks in the law greatly influences the movement of Islamic banks in the country. Islamic banks operating under Islamic banking laws will be more free to operate in sharia compared to Islamic banks operating under banking laws in general. Because of the characteristics of Islamic banks that are typical and different from conventional banks, Islamic banks will be shackled by their mobility if they are limited by conventional banking laws. For example, Islamic banks under conventional bank laws may not be allowed to buy and sell goods, they may not be permitted to lease goods, and so on. In fact, Islamic banks are allowed to use a sale and purchase contract (murabahah, salam, or istishna) or rent (ijarah or ijarah muntahiya bittamlik).

Product development policies or approaches chosen by the sharia banking authorities also determine the products and services offered to customers. A product development approach which is careful in applying Sharia principles will lead to products and services that are always compliant to Shariah principles. Syariah in accordance with Sharia principles. Consequently, product development is slower. Conversely, a pragmatic-marketdriven product development approach will generally lead to a variety of products along with similar products in conventional banking. This approach generally adheres to sharia provisions that are more lax, so that the instruments and products produced are creative and innovative following market demand.

With these different products, services, 
and Islamic financial instruments which are available and marketed in one country may not exist and are not offered in other countries because the country's scholars believe that the contract used is not in accordance with Sharia principles and the schools adopted by the state or Muslim in the country. For example, the BBA contract (BBA) in Malaysia is not used in the Middle East or in Indonesia, because the BBA uses the Bai 'al-Inah contract in it, which is considered by Middle Eastern scholars and Indonesian scholars not in accordance with Sharia principles. These differences make Islamic world products, services and financial instruments very divergent, various, and have no standards. Therefore international financial institutions such as IFSB (Islamic Financial Services Board) and AAOIFI (Accounting and Auditing Organization of Islamic Financial Institution) are two Islamic financial institutions which task is to converge, standardize products and operations of Islamic banks internationally. ${ }^{2}$

\section{METHOD}

Normative legal research is a type of legal research used in this study. Normative legal research will rely on a method with a focus on library law research using library materials, as well as applicable laws and regulations.

In this legal research a Comparative Approach is used where the comparative approach is carried out by comparing the laws of a country with the laws of one or more other countries regarding the same thing, but it can also be compared in the same law which are the court decisions in several countries for the same case ${ }^{3}$

$2 \quad$ Ibid Page 8.

3 Peter Mahmud Marzuki. 2010. Penelitian Hukum. Kencana Jakarta: Prenada Media Group, hlm.95
Primary legal materials that will be used in the writing, compilation and presentation of this legal research are the legal provisions in the Sharia Banking Act, as well as secondary legal materials related to books, literature, written results of legal experts and doctrines relevant to the discussion on legal research this.

The technique of gathering legal material in this research uses document studies (literature studies). Analysis of primary legal materials and secondary legal materials were carried out by the method of systematic interpretation, then interpreted with the formulation of research problems related to the factors and effects of legal products from the two countries to obtain a more comprehensive study and the relationship between legal products and the development of Islamic banking in Indonesia and Malaysia.

\section{ANALYSIS AND DISCUSSION Overview of the Society in Malaysia and Indonesia}

Malaysia is a country that consists of various ethnic groups with diverse religious followers, consisting of Muslims 58\%, Hindus $8 \%$, Christians $24 \%$ and others $10 \%$. However, the official state religion is Islam. Therefore, the Malaysian government has an obligation to accommodate the development of Islamic financial institutions in Malaysia in accordance with the Islamic religion adopted by the state and the majority of the people. On that basis, Malaysia began implementing dual economic systems and developing Islamic financial and banking systems since 1983 .

Indonesia is the largest archipelagic country in the world with diverse ethnicities, languages, and religions with a population of 240 million. Although it is not an Islamic country, 
Indonesia is a country with the largest Muslim population in the world with a population of Muslims as much as $88 \%$, Christians 5\%, Catholics 3\%, Hindus 2\%, Buddhists $1 \%$, and others $1 \%$. With the increasingly advanced financial and banking systems as well as the increasing welfare, the needs of the people, especially Muslims, who want banking services that are in accordance with the principles of Sharia religion that he adheres to become even greater.

\section{Regulation of Sharia Banking in Malaysia and Indonesia}

Islamic banks in Malaysia are under different laws depending on the form of institution. The full fledged Islamic bank is under the Islamic Banking Act issued in 1983. Meanwhile, Islamic windows or conventional banks that offer sharia banking products are under conventional banking laws. With the different laws governing it, full fledged Islamic bank operations are more flexible than Islamic windows, especially in the application of Sharia provisions. In addition, the Sharia banking law of 1983 is a civil law so that it remains under the jurisdiction of the civil court. ${ }^{4}$ This situation has implications that although with the Shariah banking law of 1983 Islamic banks can apply Sharia values in their operations, but it is not enough to cover conventional banking laws to reflect the pure concept of buying and selling (al-bai '). In accordance with banking laws, Islamic banks or conventional banks may only provide financing facilities. Banks are not allowed to buy and sell assets for profit. investment banking, merchant banking, leasing company, investment agent, and as an institution of zakat, infaq and sadaqah. The difference in opera-

4 Ibid Page 10. tions between BUS and UUS is almost absent except in terms of freedom of management policy. BUS is its own business entity that has policy independence, so it has autonomy in choosing its business strategy and development. Meanwhile, UUS is part of its parent conventional bank, so it lacks the freedom to determine management policies. ${ }^{5}$

Islamic banks in Indonesia, whether in the form of Islamic public banks or BUS (full fledged Islamic banks), sharia business units or UUS (full branch Islamic banks), or sharia people's credit banks or BPRS, are under banking law (Law No .10 of 1998). Banking operations with Sharia principles are fully accommodated by law. Thus, Islamic banks in Indonesia can make transactions based on deposits, loans, for results, buying and selling, leasing, and other principles permitted by Sharia. Thus Islamic banks in Indonesia are universal banks that can try as consumer banking, investment banking, merchant banking, leasing companies, investment agents, and as anstitution of zakat infaq and sadaqah amil. The difference in operations between BUS and UUS is almost none, except in terms of freedom of management policy. BUS is its own corporate entity that has policy independence, so it has an autonomy in choosing its business strategy and development. Meanwhile, UUS is part of its parent conventional bank, so it lacks the freedom to determine management policies.

$5 \quad$ Abdullah Saeed. 1999. Islamic Banking and Interest: A study of the Prohibition of Riba and its Contemporary Interpretation. EJ Brill: Leiden, p. 32. 


\section{Differences of Sharia Banking in Gen- eral Aspects between Malaysia and In- donesia}

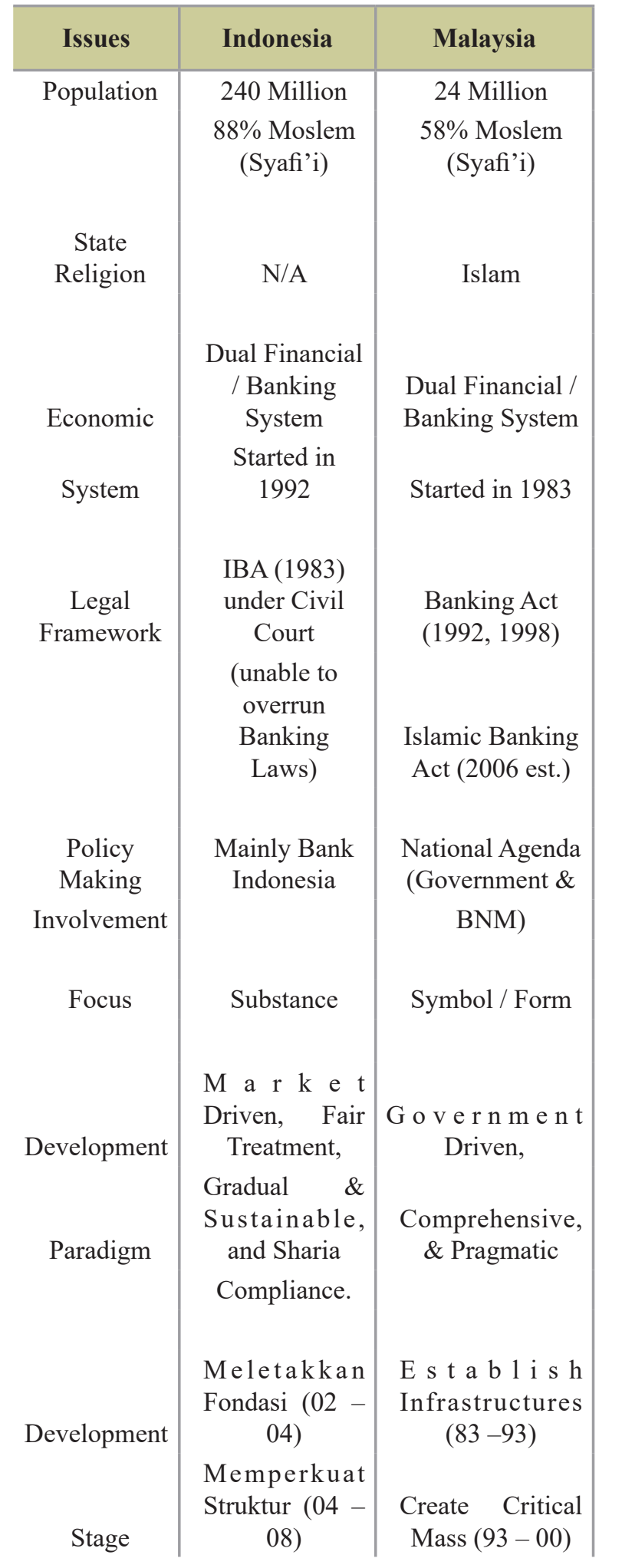

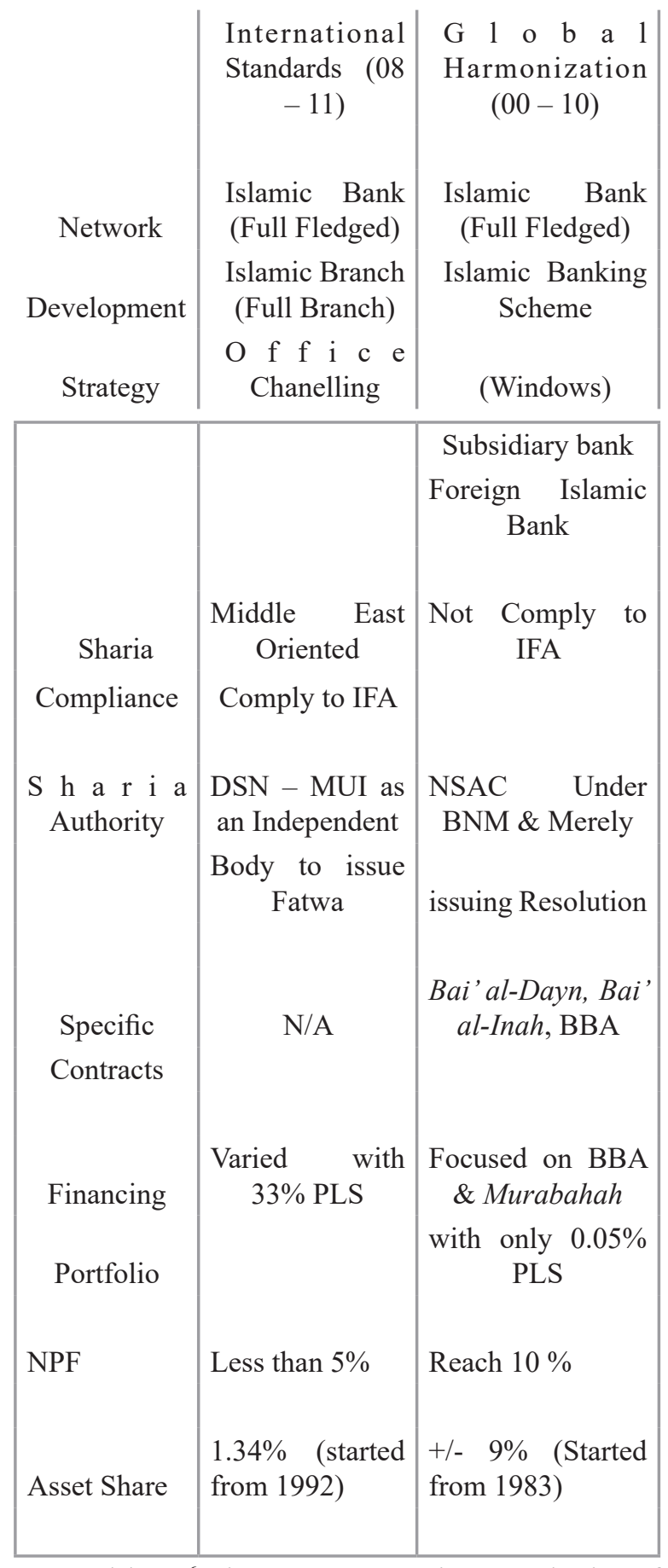

Table $1^{6}$, in a comparative analysis of the application of sharia principles to $\mathrm{Ma}$ laysian and Indonesian Islamic banks, Malaysian banks implemented products based

6 M.S. Abd. Majid and Amri. 2010. "Perbankan syariah di Indonesia: Antara tantangan dan harapan”. Jurnal Perspektif Manajemen dan Perbankan, 1(2):53. 
on the principles of Bai 'al-Inah and Bai' al-Dayn which were not approved by the Islamic Fiqh Academy (IFA), while Indonesian banking was in line with the IFA, which does not apply these two principles.

Comparing Indonesian and Malaysian banks, we must also pay attention to both of the country environmental conditions, for example the Malaysian environment which is more concerned with the symbolization of the implementation of Islamic practices, meaning more attention to symbolic issues than the issue of the substance of the application of Islamic banking that adheres to sharia principles. This is related to the Muslim population which is relatively not dominant so that the implementation of Islamic practices becomes a representation of maintaining the existence of Muslim society, so that the attention to the compliance of Islamic principles is still not the main focus. On the contrary, what happened in Indonesia, with a population that was so dominant and the demands of the Muslim community who hoped for banking operations in an ideal form, Islamic banking oparational must pay attention to the substance, especially operational compliance with sharia principles. From one side this is seen as a positive trend, because there has been a supervision by the community. Besides that the development of Islamic banking in Malaysia is a national agenda, in contrast to Indonesia where the development of Islamic banking is dominated by The Bank Indonesia initiatives.

In the development of Malaysian Islamic banking it seems that the issue of sharia compliance is relatively not a concern. This should be a competitive advantage for the Indonesian Islamic banking industry, where in the development of the sharia banking industry in Indonesia, compliance with sharia principles is one of the basic considerations in industrial development. This advantage can be used as a strong capital in the promotion to attract foreign investors (especially the Middle East who are currently enjoying petro dollars due to the increase of world crude oil prices). Meanwhile, financing channeled by Malaysian Islamic banking is dominated by Bai 'Bithaman Ajil (BBA) and Murabahah portfolios where the share of the share of profit sharing is only $0.05 \%$. On the contrary, the financing portfolio in Indonesian Islamic banking is relatively various, where the profit sharing portfolio reaches $33 \%$.

\section{Sharia Banking Development Strategy in Malaysia and Indonesia}

The long-term goal to be achieved in the development of Islamic banking in Malaysia is to create a comprehensive Islamic financial and banking system that operates parallel to the conventional banking system. To create a strong banking system, the three important needed elements are: 1) a large number of players; 2) wide variety of instruments; and 3) Islamic money market. The chosen development strategy is the development of a comprehensive, gradual, and pragmatic, which begins with the stages to create an enabling environment by preparing various financial infrastructure, especially the legal framework. The next stage is to increase the volume and create a market for Islamic financial institutions, so that Islamic financial institutions can compete. The third stage is to create harmonization and convergence with the international Islamic financial market so that Malaysian Islamic financial institutions can compete internationally.

The first phase of development began with the issuance of the Islamic Banking Act (IBA) on April $7^{\text {th }}, 1983$. With the promulgation of 
the IBA, Bank Negara Malaysia (BNM) was authorized to regulate and supervise Islamic banks, as well as conventional banks. The first Islamic bank was Bank Islam Malaysia Berhad (BIMB) which began operations on July 1, 1983 with a total asset of RM 369.8 million or equivalent to Rp. 1,035 trillion (RM 1 = Rp. 2,800). In 1983 a Government Investment Act (GIA) was also issued which authorized the government to issue Government Investment Issues (GII) which were the securities issued by the government based on Sharia principles. GII is a form of Islamic financial instruments needed for the management of Islamic bank liquidity needs.

After that, in 1984 the Takaful Act was issued which became the legal foundation of sharia insurance to operate as one of the supporting infrastructure for Islamic banking. The first Islamic insurance company was Syarikat Takaful Malaysia which was established in the same year. Other provisions issued in this first stage are the obligations of banks and sharia insurance to have a Sharia Supervisory Board which the task is to ensure that operations and banking and sharia insurance products are in accordance with Sharia provisions.

The second phase of development began on the fourth of March 1993 by introducing the "Free Banking Scheme" or SPTF (Interest Free Banking Scheme). With this scheme conventional banks are allowed to offer Islamic banking products, or commonly called Islamic Windows. With this strategy the number of bank offices offering Sharia products is increasing rapidly, effectively and efficiently. It is because the sharia banking

7 Bank Islam Malaysia Berhad. 1994. Islamic Banking Practice from Practitioner's Perspective, Kuala Lumpur : Banking law (Islamic law). p. 93. service outlets have increased in a short time as many as existing bank office networks and conventional financial institutions which are initiated by three banks and 54 financial institutions as pilot projects. In the following year, in 1994, the Islamic Interbank Money Market was established on January $4^{\text {th }}$ to connect Islamic financial institutions through Sharia money market instruments, which also became a milestone in the development of Islamic financial instruments. Meanwhile, the sharia capital market followed in 1996 which encouraged the development of Sharia securities. As an effort to smooth and harmonize interpretations of Sharia provisions, a Sharia Advisory Board for Islamic Banking and Insurance was established on May $1^{\text {st }}$ (National Sharia Advisory Council on Islamic Banking and Takaful or NSAC), as the highest Sharia authority in banking and sharia insurance in Malaysia. In addition, during this second phase of development, the second Islamic bank was established on October $1^{\text {st }} 1999$, named Bank Muamalat Malaysia Berhad or BMMB, and three Islamic insurance companies which were granted an operating license, named Takaful National Sdn. Berhad, Maybank Takaful Berhad, and Takaful Ikhlas Sdn. Berhad.

The third phase of development begins with the creation of the FSMP Financial Sector Master Plan in 2000 for the period 2000 - 2010 which covers the Islamic finance sector. FSMP for sharia banking and insurance is divided into three phases, which are: 1) Strengthening operational and institutional infrastructure; 2) Stimulating competition and improving infrastructure; and 3) Improving performance standards through progressive liberalization and ensure effective infrastructure. To support FSMP, a review of the Islamic 
Windows strategy was carried out which still caused debate about its compliance with Sharia provisions and issued provisions in 2004 to encourage Islamic Windows to transform into an Islamic Subsidiary. In the same year, the liberalization of banking and sharia insurance was carried out by issuing permits for three foreign sharia financial institutions and four Takaful with the participation of foreign parties. In addition, at this stage efforts were also made to: 1) improve regulatory, prudential and operational frameworks; 2) review the legislative process and the court; 3) develope the Sharia governance framework by establishing the National Shariah Advisory Council at BNM and Shariah Committees in Islamic financial institutions; and 4) form endowment funds for sharia experts to support their role.

On the basis of encouraging people needs for Islamic banking services, the first Islamic bank was established in 1992 and the Indonesian government began introducing the dual banking system. The Government's commitment in developing sharia banking has only begun to be felt since 1998 which provides wide opportunities for Islamic banks to develop. The following year Bank Indonesia (the central bank) was given the mandate to develop Islamic banking in Indonesia. In addition to adhering to a market-driven and fair-treatment strategy, the development of Islamic banking in Indonesia is carried out with a gradual and sustainable approach in accordance with Sharia principles (comply to Sharia principles). The first stage was intended to lay the foundation for a strong growth of Islamic banking (2002 - 2004). The next phase enters a phase to strengthen the structure of the Islamic banking industry (2004 - 2008). Meanwhile, the third stage of Islamic bank- ing is directed to be able to reach international financial and service quality standards (2008 - 2011). In 2011, it is expected that Indonesian Islamic banking has a significant share that will take part in developing the Indonesian economy which will prosper the wider community.

\section{Comparison of Products}

Islamic banking products and services in Malaysia vary greatly to more than 40 types of sharia financial products and services using various contracts. These products and services include products and services for funding, financing, trade finance, banking services, card services, treasury and money market instruments. These products and services are very similar to the products and services offered by conventional banking. The naming of sharia products and services follows the name of conventional products and services by adding the initials ' $i$ ' behind which indicates that the product or service is a product or service that uses sharia principles (Islamic). For example, savings or savings accounts are named savings account-i, project financing is named project financing-i etc.

\section{Regulations Malaysian Sharia Banking}

Moeslem is the official religion in Malaysia. This is as stated in Federal Constitution Article 3 (a) which quotes: "Moeslem is a federation religion; But other religions can also be peaceful and dangerous in the state ".

Sharia banking in Malaysia under the auspices of the Central Bank, BNM adopts a dual banking system, when the sharia banking operates side by side with conventional banking. As a central bank, BNM holds full authority to control and regulate banking operations in the country. Similar to conventional banks, Islamic banks are also under the supervision and regulation of $\mathrm{BNM}$, as an authoritative 
body that has the right and comprehensive legal force to regulate and supervise the financial system in Malaysia based on the Central Bank of Malaysia Act 1958

in principle, The Sharia banking operations in Malaysia have two main legal bases, named Sharia banking Act (IBA) 1983, and the Banking and Financial Institutions Act (BAFIA) 1989. IBA 1983 specifically regulates Islamic banks where Islamic teachings can be applied in the banking business. This law does not contain provisions relating to any banking business, or even The Sharia banking business carried out by the conventional banks. The birth of this Act has opened the way for the formation of Islamic banks in Malaysia. In contrast, the 1989 BAFIA was enacted to regulate conventional banks, including those operating Sharia banking business in addition to the interest-based business.
This Act is actually an amalgamation of two existing legal products, namely the Financial Companies Act 1969 and the 1963 Insurance Act. The birth of BAFIA 1989 has provided a legal basis for financial institutions to carry out the sharia banking business under certain conditions. The only provisions of the Sharia banking business carried out by conventional banks are regulated in article 124 (1) which states:

"Except as provided in section 33, nothing in this Act or Sharia banking Act 1983 prohib prohibit or restrict any licensed institution consult the bank before it carries on the sharia banking business or any Islamic financial business. " the sharia and the conventional banks which are not covered by the above Act, it is regulated in other relevant laws and some of the sharia banking guidelines issued by BNM.

\begin{tabular}{|c|c|c|}
\hline Regulation & Sharia Banking & Conventional Banking \\
\hline & Establishment & Establishment \\
\hline $\begin{array}{l}\text { Companies Act } 1965 \\
\text { Central Bank Act } \\
\text { (CBA 1958) }\end{array}$ & $\begin{array}{l}\text { Sharia Formation Advisory } \\
\text { Council (SAC) }\end{array}$ & $\begin{array}{l}\text { Sharia Formation Advisory } \\
\text { Council (SAC) }\end{array}$ \\
\hline \multirow{2}{*}{$\begin{array}{l}\text { Islamic Bank Act } \\
\text { (IBA 1983) }\end{array}$} & $\begin{array}{l}\text { Licence } \\
\text { Supervision } \\
\text { Management }\end{array}$ & \\
\hline & Sharia establishment & \\
\hline $\begin{array}{l}\text { Banking and Financial } \\
\text { Institutions Act (BAFIA) } \\
1989\end{array}$ & & $\begin{array}{l}\text { Licence } \\
\text { Supervision } \\
\text { Management } \\
\end{array}$ \\
\hline $\begin{array}{l}\text { Guidelines on skim } \\
\text { Banking without benefits } \\
\text { (SPTF) } 1993\end{array}$ & & $\begin{array}{l}\text { Islamic Banking Business } \\
\text { Products } \\
\text { Requirements and Procedure } \\
\text { for Establishing IBU } \\
\text { (Islamic Banking Unit ) }\end{array}$ \\
\hline
\end{tabular}




\begin{tabular}{|c|c|c|}
\hline $\begin{array}{l}\text { Guidelines on } \\
\text { the Governance } \\
\text { of Shariah } \\
\text { Committee for the } \\
\text { Islamic Financial } \\
\text { Institutions (BNM/ } \\
\text { GPS1) } 2004\end{array}$ & $\begin{array}{l}\text { Duties and responsibilities Haria } \\
\text { Replied Committee }\end{array}$ & $\begin{array}{l}\text { Duties and responsibilities } \\
\text { Haria Replied Committee } \\
\text { members }\end{array}$ \\
\hline $\begin{array}{l}\text { Cental Banking } \quad \text { Act } \\
\text { (CBA 2009) }\end{array}$ & $\begin{array}{l}\text { BNM Authority to make } \\
\text { Malaysia as International Islamic } \\
\text { Financial Hub. }\end{array}$ & \\
\hline
\end{tabular}

Table 2. Regulations Malaysian Sharia Banking

\section{Regulations Indonesia Sharia Banking}

The Sharia banking regulations eventually narrowed to Law No. 21 of 2008 concerning Islamic Banking. In conducting sharia banking business activities, Indonesian sharia banks must be guided by sharia principles. The Sharia principle referred to this Law, stipulated in Article 1 number 12, which is "the principle of Islamic law in banking activities based on fatwas issued by institu- tions that have the authority to determine fatwas in the matter of sharia". The principles of Islamic law which form the basis of the implementation of Islamic banking activities are determined that there is a fatwa prepared by the authorized institution. Regarding the institution authorized to issue a fatwa, it can clearly be seen in the provisions of Article 26
Law No 21 (2008) concerning Sharia Bank

\section{Regulation}

\begin{tabular}{|c|c|c|}
\hline Regulation & Sharia Banking & Conventional Banking \\
\hline $\begin{array}{l}\text { Law No } 21 \text { (2008) concerning } \\
\text { Sharia Bank }\end{array}$ & $\begin{array}{l}\text { Licence } \\
\text { Prudent Supervision } \\
\text { Management } \\
\text { Transver of convensional to } \\
\text { sharia bank } \\
\text { Punishment \& Law }\end{array}$ & \\
\hline $\begin{array}{l}\text { UU No. } 23 \text { (1999) } \\
\text { About Bank Indonesia }\end{array}$ & $\begin{array}{l}\text { Bank Indonesia must support } \\
\text { the sharia bank business }\end{array}$ & $\begin{array}{l}\text { Bank Indonesia must support } \\
\text { the sharia bank business }\end{array}$ \\
\hline \multirow{5}{*}{$\begin{array}{l}\text { BINo Regulation. } 624 \text { / PBI/ } 2004 \\
\text { concerning Banks Commercial ones } \\
\text { doing Sharia business principles } \\
\text { Amended inside BI Regulation No. } \\
735 \text { / PBI/ } 2005\end{array}$} & $\begin{array}{l}\text { Requirements \& } \\
\text { Procedures for establishing } \\
\text { legal products } \\
\text { Products } \\
\text { Board Formation }\end{array}$ & \\
\hline & Sharia Advisors & \\
\hline & & \\
\hline & & \\
\hline & & \\
\hline
\end{tabular}




\begin{tabular}{l|l|l|}
\hline & & \\
\hline & $\begin{array}{l}\text { Requirements \& Procedures } \\
\text { Formation / Transfer } \\
\text { Products } \\
\text { Products }\end{array}$ & \\
$\begin{array}{l}\text { BIRegulation No. 83/PBI/2006 } \\
\text { About Business transfer Comercial } \\
\text { Bank Convention to the Bank } \\
\begin{array}{l}\text { Comercial ones doing business } \\
\text { Sharia principles and founders haria }\end{array}\end{array}$ & \\
$\begin{array}{l}\text { Advisors UUS by Conventional } \\
\text { Commercial Bank }\end{array}$ & \\
\hline $\begin{array}{l}\text { BI Regulation No 7/46/ } \\
\text { PBI/2005 concerning Funf } \\
\text { mobilization and financing } \\
\begin{array}{l}\text { Agreement for Business Bank } \\
\text { Sharia Principles }\end{array}\end{array}$ & $\begin{array}{l}\text { Contract requirements } \\
\text { deep financial agreement } \\
\text { banking business sharia }\end{array}$ & $\begin{array}{l}\text { Contract requirements deep } \\
\text { financial agreement banking } \\
\text { business sharia }\end{array}$ \\
\hline $\begin{array}{l}\text { Circular No. } \\
\text { 8/19/DPBS All Commercial Banks } \\
\text { who carry out Sharia business } \\
\text { principles, Islamic supervision \& } \\
\text { sharia }\end{array}$ & $\begin{array}{l}\text { Duties \& Responsibilities } \\
\text { replied the member board } \\
\text { of trustees sharia and } \\
\text { activity sharia supervision }\end{array}$ & $\begin{array}{l}\text { Duties \& Responsibilities } \\
\text { replied the member board } \\
\text { of trustees sharia and } \\
\text { activity sharia supervision, }\end{array}$ \\
\hline
\end{tabular}

Table 3. Regulations Indonesia Sharia Banking

\section{CONCLUSION}

There is a difference in the level of development of the Islamic banking industry between Malaysia and Indonesia due to the different approaches adopted by each country in providing a legal response to the emergence of The Islamic banking. The Islamic banking regulations in Malaysia have been very adequate even since the first Islamic bank (BIMB) appeared. Meanwhile, in Indonesia, 16 years after the first Islamic bank (BMI) operated, the new Islamic banking regulation was promulgated. The elimination of double taxes and the settlement of sharia business disputes has only been set up since 2010 . Though this regulation has been established in Malaysia before BIMB was born. Unlike in Indonesia, in fact, the Malaysian government has previously established regulations on Is- lamic banking before the first Islamic banking was established in 1983. Whereas in Indonesia, the regulation only emerged after 16 years the Islamic bank operated. This difference has affected the rate of growth and development of Islamic banking in each country. Islamic banking in Malaysia has shown steady and fast progress compared to Indonesia.

\section{BIBLIOGRAPHY}

Rosly, Saiful Azhar 2005. Critical Issues on Islamic Banking and Financial Markets. Kuala Lumpur, Malaysia :Dinamas Publishing,

Saeed, Abdullah.1999. Islamic Banking and Interest: A study of the Prohibition of Riba and its Contemporary Interpretation. EJ Brill: Leiden.

Ascarya .2006. Comparing Islamic Banking 
Development in Malaysia and Indonesia: Lessons for Instruments Development. Jakarta: Center for Central Banking Education and Studies Bank Indonesia.

Majid, M.Shabri Abd. 2014. "Regulasi Perbankan Syariah: Studi Komparatif Antara Malaysia Dan Indonesia”. jurnal Media Syariah, 16(1): 235

Marzuki, Peter Mahmud. 2010. Penelitian Hukum. Jakarta: Prenada Media Group S, Abd. Majid, M. and Amri. 2010. "Perbankan syariah di Indonesia: Antara tantangan dan harapan". Jurnal Perspektif Manajemen dan Perbankan, 1(2):53.

Anshori, Abdul Ghofur. 2008. "Sejarah
Perkembangan Hukum Perbankan Syariah di Indonesia dan Implikasinya bagi Praktik Perbankan Nasional", $\quad$ La Riba:Jurnal Ekonomi Islam, 2(2) Berhad, Bank Islam Malaysia. 1994. Islamic Banking Practice from Practitioner's Perspective, Kuala Lumpur: Banking Law(Islamic Law). 